\title{
Air Quality Characteristics of China's Bohai Bay Area
}

\section{Mingshi Wang, Yanping Liu, Chenlu Gui, Zhaofeng Xu, Wei Wu*}

Institute of Resources and the Environment, Henan Polytechnic University, Jiaozuo, Henan, China

Received: 12 March 2018

Accepted: 12 September 2018

\begin{abstract}
In recent years, with the rapid economic development of Bohai Economic bay area in China, the atmospheric environmental pollution problem has been of wide concern and has attracted great public attention. In this paper, the data of $\mathrm{PM}_{10}, \mathrm{SO}_{2}, \mathrm{CO}, \mathrm{NO}_{2}, \mathrm{O}_{3}$ and $\mathrm{PM}_{2.5}$ in 12 cities located around the Bohai Bay area of China were collected in 2016. These 12 cities were divided into coastal and non-coastal areas according to distance from the sea. On the basis of data analysis, the air quality pollution and its distribution in the bay area were researched. The results indicated that the rates failing to comply with National Ambient Air Quality Standard (NAAQS) of $\mathrm{PM}_{2.5}$ were $6.39 \%$ and $34.15 \%$ in coastal cities and non-coastal cities, respectively, and the noncompliance rates of $\mathrm{PM}_{10}$ were $12.84 \%$ and $28.96 \%$, respectively, with $\mathrm{O}_{3}$ exceeding $23.50 \%$ and $31.69 \%$, respectively, and noncoastal cities were higher than the coastal cities. If complying with WHO's concentration limit of $\mathrm{PM}_{2.5}\left(10 \mu \mathrm{g} / \mathrm{m}^{3}\right)$, the number of noncompliance days is 7.4 times as high as that of NAAQS, and some cities could even not meet the standard throughout the year. There are significant differences between $\mathrm{PM}_{2.5}$ in coastal cities and non-coastal cities due to the air mass and its own industrial differences, while the difference on $\mathrm{O}_{3}$ is not significant due to similar sources of pollution in the bay area. The pollution situation in the bay area showed that $\mathrm{PM}_{2.5}$ had heavy pollution in January, March, November and December, while the atmosphere in July, August and September was the least polluted and did not show the "weekend effect" due to the effects of the local economy. On the whole, there is still a serious problem of air pollution in the Bohai Bay area.
\end{abstract}

Keywords: Bohai Bay, pollution factor, coastal city, non-coastal city

\section{Introduction}

In recent years, with the rapid development of China's economy, pollutant emissions have gradually increased and atmospheric environmental quality is

*e-mail: 120248396@qq.com

declining [1]. Among them, the regional compound air pollution, which is mainly polluted by ozone and fine particles $\left(\mathrm{PM}_{2.5}\right)$, is especially significant [2-3]. $\mathrm{PM}_{2.5}$ not only reduces visibility, but also serves as a carrier of heavy metal elements, organic matter, viruses and bacteria and other toxins that can invade the human respiratory and circulatory systems, endangering human health [4]. Researches have confirmed that the main sources of $\mathrm{PM}_{2.5}$ in China are the combustion of coal and 
biomass, secondary nitrate or sulfate, soil, dust and so on [5]. The weekly trend of mass concentration is highly correlated with human activity [6], whereas the peak of the concentration value is mainly in the heating period, such as in January, February, March, November and December [7]. At present, there are some achievements in the study of $\mathrm{PM}_{2.5}$ concentrations [8-9], source analysis [10], transmission and diffusion of pollutants [11] and so on. However, most of these studies have focused on inland cities, with relatively few studies of coastal cities. Recently, air pollution problems in coastal cities of China have become more and more serious, and air pollution problems occur more frequently [1213]. Thus air pollution issues have gradually become hotspots of current research.

The Bohai Bay area occupies an important strategic position in China's economic development. However, the heavy industry cities, represented by Tangshan, Tianjin and Dalian, have also brought serious environmental problems to the area. Therefore, this paper analyzes the pollution situation of $\mathrm{PM}_{25}$ and related factors in the Bohai Bay area, studies the temporal and spatial characteristics, discusses its influencing factors, and provides the basis for pollution control in the area.

\section{Material and Methods}

\section{Data Sources}

The data of $\mathrm{PM}_{10}, \mathrm{SO}_{2}, \mathrm{CO}, \mathrm{NO}_{2}, \mathrm{O}_{3}$ and $\mathrm{PM}_{2.5}$, which is from January 2016 to December 2016, are from the China Environmental Monitoring Station "National Urban Air Quality Real-time Release Platform.”

\section{Study Areas and Methods}

This study chose 12 cities around China's Bohai Bay area. According to the geographical distribution and

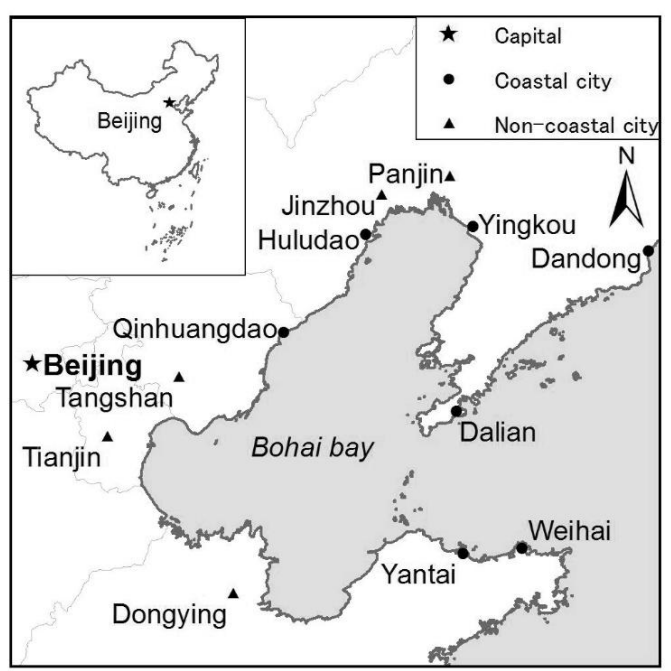

Fig. 1. Spatial distribution of the Bohai Bay area. urban distance from the sea, the 5 cities of Dongying, Jinzhou, Panjin, Tangshan and Tianjin are defined as non-coastal cities, and Dalian, Dandong, Weihai, Yantai, Yingkou, Qinhuangdao and Huludao are defined as coastal cities (Fig. 1). The correlation analysis and independent-samples test of $\mathrm{PM}_{10}, \mathrm{SO}_{2}, \mathrm{CO}, \mathrm{NO}_{2}, \mathrm{O}_{3}$ and $\mathrm{PM}_{2.5}$ were carried out through SPSS, and the spatial characteristics of $\mathrm{PM}_{2.5}$ and $\mathrm{O}_{3}$ were studied by ArcGIS software.

\section{Results and Discussion}

\section{Concentration Characteristics of Various Pollution Factors}

The research results showed that the annual average concentration ranges of $\mathrm{PM}_{2.5}, \mathrm{PM}_{10}, \mathrm{SO}_{2}, \mathrm{CO}$, $\mathrm{NO}_{2}$ and $\mathrm{O}_{3}$ in coastal cities were $33.6 \sim 46.8 \mu \mathrm{g} / \mathrm{m}^{3}$, $62.9 \sim 87.7 \mu \mathrm{g} / \mathrm{m}^{3}, \quad 22.2 \sim 47.2 \mu \mathrm{g} / \mathrm{m}^{3}, \quad 0.61 \sim 1.4 \mu \mathrm{mg} / \mathrm{m}^{3}$, $21.9 \sim 47.4 \mu \mathrm{g} / \mathrm{m}^{3}$, and $94.3 \sim 126.1 \mu \mathrm{g} / \mathrm{m}^{3}$; the annual average concentration ranges in non-coastal cities were $39.2 \sim 73.8 \mu \mathrm{g} / \mathrm{m}^{3}, \quad 67.8 \sim 127.9 \mu \mathrm{g} / \mathrm{m}^{3}, \quad 21.0 \sim 51.8 \mu \mathrm{g} / \mathrm{m}^{3}$, $0.85 \sim 2.3 \mathrm{mg} / \mathrm{m}^{3}, \quad 27.7 \sim 58.3 \mu \mathrm{g} / \mathrm{m}^{3}$, and $96.8 \sim 131.1 \mu \mathrm{g} / \mathrm{m}^{3}$. According to the annual average concentration of pollutants in different cities during the study period (Table 1), it can be found that the concentration of pollution factors in non-coastal cities is generally higher than that of coastal cities.

\section{Excessive Situation of Pollution Factors}

Table 2 shows that the noncompliance phenomenon of $\mathrm{PM}_{2.5}, \mathrm{PM}_{10}$ and $\mathrm{O}_{3}$ in the Bohai area is serious, and $\mathrm{PM}_{2.5}$ pollution is the most serious. At the same time, the noncompliance rates of the 3 pollution factors are all non-coastal cities higher than the coastal cities. If taking the concentration limit of $\mathrm{PM}_{25}$ specified by WHO $\left(10 \mu \mathrm{g} / \mathrm{m}^{3}\right)$ as the standard for calculation of the number of noncompliance days, the coastal and non-coastal cities are seriously exceeded, and exceeding the standard of 7.4 times, and some cities even could not meet the standard throughout the year, which implies that the $\mathrm{PM}_{25}$ pollution problem in the Bohai Bay area is extremely serious.

The noncompliance rates of $\mathrm{SO}_{2}$ and $\mathrm{CO}$ are both relatively small. Especially for $\mathrm{SO}_{2}$, there is only one city in the coastal and non-coastal cities that has exceeded the standard. The reason may be that $\mathrm{SO}_{2}$ is released mainly from coal-fired emissions, while $\mathrm{NO}_{2}$ is mainly from coal-fired emissions, urban vehicle exhaust and industrial production processes [14-16]. In 1973, thermal power plant flue gas desulfurization began to be taken seriously when China's environmental protection agencies were established. Afterward, China introduced the national $10^{\text {th }}$ Five-Year Plan for Environmental Protection and the national $11^{\text {th }}$ Five-Year Plan for Environmental Protection, which were given higher attention and required the installation of flue 
Table 1. Concentration characteristics of pollution factors in coastal and non-coastal cities $\left(\mathrm{mg} / \mathrm{m}^{3}\right.$ for $\mathrm{CO}, \mu \mathrm{g} / \mathrm{m}^{3}$ for other pollution factors) ${ }^{\mathrm{a}}$

\begin{tabular}{|c|c|c|c|c|c|c|c|}
\hline \multirow{7}{*}{ Coastal Cities } & City & $\mathrm{PM}_{2.5}$ & $\mathrm{PM}_{10}$ & $\mathrm{SO}_{2}$ & $\mathrm{CO}$ & $\mathrm{NO}_{2}$ & $\mathrm{O}_{3}$ \\
\cline { 2 - 7 } & Dalian & $38.53 \pm 28.8$ & $68.17 \pm 44$ & $25.82 \pm 20.0$ & $1.00 \pm 0.3$ & $30.30 \pm 11$ & $114.69 \pm 42.3$ \\
\cline { 2 - 7 } & Dandong & $42.15 \pm 24.3$ & $70.67 \pm 44$ & $29.63 \pm 25.6$ & $1.35 \pm 0.4$ & $25.10 \pm 10.9$ & $96.66 \pm 39.7$ \\
\cline { 2 - 7 } & Waihai & $33.78 \pm 22.5$ & $62.88 \pm 44$ & $14.47 \pm 9.1$ & $0.61 \pm 0.2$ & $21.93 \pm 12.4$ & $106.90 \pm 42.3$ \\
\cline { 2 - 7 } & Yantai & $39.64 \pm 29.0$ & $75.55 \pm 45.8$ & $22.22 \pm 11.0$ & $0.79 \pm 0.4$ & $34.67 \pm 15.1$ & $102.67 \pm 36.3$ \\
\cline { 2 - 8 } & Yingkou & $44.36 \pm 31.9$ & $73.32 \pm 47.1$ & $22.64 \pm 15.2$ & $0.88 \pm 0.4$ & $28.07 \pm 12.6$ & $126.07 \pm 51.8$ \\
\cline { 2 - 8 } & Qinhuangdao & $45.97 \pm 37.5$ & $87.72 \pm 56.8$ & $27.60 \pm 18.2$ & $1.31 \pm 0.9$ & $47.38 \pm 19.4$ & $94.33 \pm 51.1$ \\
\cline { 2 - 7 } & Huludao & $46.76 \pm 35.8$ & $87.57 \pm 58.7$ & $47.17 \pm 35.3$ & $1.34 \pm 0.6$ & $35.79 \pm 16.2$ & $116.15 \pm 51.3$ \\
\cline { 2 - 8 } Non-coastal Cities & Dongying & $64.07 \pm 42.5$ & $120.00 \pm 65.5$ & $47.55 \pm 25.0$ & $1.17 \pm 0.5$ & $39.52 \pm 19.1$ & $131.10 \pm 61.2$ \\
\cline { 2 - 8 } & Jinzhou & $54.80 \pm 40.2$ & $83.28 \pm 54.5$ & $51.81 \pm 36.4$ & $1.02 \pm 0.5$ & $36.77 \pm 14.9$ & $118.74 \pm 51.8$ \\
\cline { 2 - 7 } & Panjin & $39.23 \pm 26.9$ & $67.78 \pm 42.6$ & $26.56 \pm 14.4$ & $0.85 \pm 0.4$ & $27.73 \pm 13.9$ & $124.38 \pm 51.4$ \\
\cline { 2 - 7 } & Tangshan & $73.83 \pm 57.0$ & $127.93 \pm 81.4$ & $45.69 \pm 23.4$ & $2.28 \pm 1.6$ & $58.35 \pm 20.9$ & $112.18 \pm 64.7$ \\
\cline { 2 - 7 } & Tianjin & $68.55 \pm 51.5$ & $105.83 \pm 65.3$ & $20.98 \pm 15.2$ & $1.38 \pm 0.9$ & $48.06 \pm 22.4$ & $96.79 \pm 55.0$ \\
\hline
\end{tabular}

${ }^{\mathrm{a}}$ The ambient air quality standard (GB 3095-2012) prescribes the annual average concentration limit for $\mathrm{PM}_{2.5}, \mathrm{PM}_{10}, \mathrm{SO}_{2}, \mathrm{CO}_{2} \mathrm{NO}_{2}$ and $\mathrm{O}_{3}$

gas desulphurization facilities when exceeding China's regional sulfur dioxide emissions standards or total requirements of coal-fired power plants. Nitrogen oxide emissions of thermal power plants were gradually taken into account as the emission standard air pollutants thermal power plants (GB13223-2003) was made and promulgated in 2003, which is denitrification after desulfurization first, and thus $\mathrm{SO}_{2}$ removal effect is more significant. At present, the automobile exhaust and industrial sources produced a larger proportion of $\mathrm{NO}_{2}$
[17], even after the promotion of "shifting fuel from coal to gas" in China [18], the $\mathrm{NO}_{2}$ concentration value is still high.

$$
\begin{gathered}
\text { Spatial Distribution Characteristics } \\
\text { of } \mathrm{PM}_{2.5} \text { and } \mathrm{O}_{3}
\end{gathered}
$$

Spatial distribution of $\mathrm{PM}_{2.5}$ and $\mathrm{O}_{3}$ concentrations in 2016 were obtained by spatial interpolation of the annual average concentration in the Bohai Bay area through

Table 2. Noncompliance rate of pollution factors during the study period (\%)

\begin{tabular}{|c|c|c|c|c|c|c|c|}
\hline \multirow{5}{*}{ Coastal Cities } & City & $\mathrm{PM}_{2.5}$ & $\mathrm{PM}_{10}$ & $\mathrm{SO}_{2}$ & $\mathrm{CO}$ & $\mathrm{NO}_{2}$ & $\mathrm{O}_{3}$ \\
\cline { 2 - 9 } & Dalian & 8.47 & 6.28 & 0.00 & 0.00 & 0.00 & 13.39 \\
\cline { 2 - 9 } & Dandong & 11.20 & 4.10 & 0.00 & 0.00 & 0.00 & 7.10 \\
\cline { 2 - 9 } & Waihai & 5.19 & 3.28 & 0.00 & 0.00 & 0.27 & 10.38 \\
\cline { 2 - 9 } & Yantai & 8.20 & 5.74 & 0.00 & 0.00 & 0.27 & 7.38 \\
\cline { 2 - 9 } & Yingkou & 12.57 & 6.01 & 0.00 & 0.00 & 0.00 & 23.50 \\
\cline { 2 - 9 } & Qinhuangdao & 16.39 & 12.84 & 0.00 & 1.91 & 7.10 & 11.20 \\
\cline { 2 - 9 } & Huludao & 14.21 & 11.20 & 1.37 & 0.82 & 1.91 & 18.85 \\
\cline { 2 - 9 } & Dongying & 30.60 & 28.96 & 0.00 & 0.00 & 3.55 & 31.69 \\
\cline { 2 - 8 } & Jinzhou & 20.49 & 9.56 & 0.55 & 0.00 & 1.37 & 19.67 \\
\cline { 2 - 8 } & Panjin & 7.92 & 5.46 & 0.00 & 0.00 & 0.27 & 22.40 \\
\cline { 2 - 8 } & Tangshan & 34.15 & 28.96 & 0.00 & 5.46 & 16.12 & 22.40 \\
\cline { 2 - 8 } & Tianjin & 31.42 & 18.31 & 0.00 & 1.37 & 8.74 & 15.30 \\
\hline
\end{tabular}

Note: The noncompliance rate of each pollution factor is based on the Chinese Ambient Air Quality Standards Grade II limit for the calculation. 
ArcGIS10.2 (Figs 2-3). From the spatial distribution point of view, $\mathrm{PM}_{2.5}$ concentrations in non-coastal cities were higher than coastal cities. In the independentsamples test, the observed value of $F$ statistic was 5.970 and the corresponding probability $\mathrm{P}$ value was 0.035 , which was less than 0.05 , and the variance of the two populations was significantly different. The observed value of T statistic is -2.924 , and $\operatorname{Sig}(2$-tailed) is 0.036 , which is less than 0.05 , and it can be concluded that there are significant differences between $\mathrm{PM}_{2.5}$ in coastal and non-coastal cities.

From the spatial distribution of $\mathrm{O}_{3}$ concentration, Panjin, Yingkou, Jinzhou, Huludao, and Dongying showed higher $\mathrm{O}_{3}$ concentrations than other cities, and the pollution is rather serious. In the case of independentsamples test, we found that the concentration of $\mathrm{O}_{3}$ in coastal and non-coastal cities was not significant. $\mathrm{O}_{3}$ is mainly derived from industrial pollution combustion, VOCs generated during the production process, and

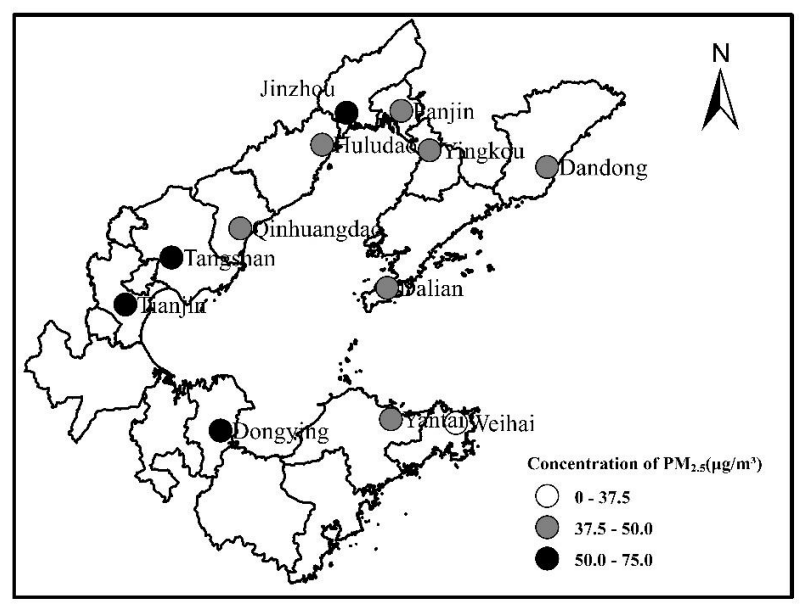

Fig. 2. Spatial distribution of $\mathrm{PM}_{2.5}$ concentrations in the Bohai Bay area.

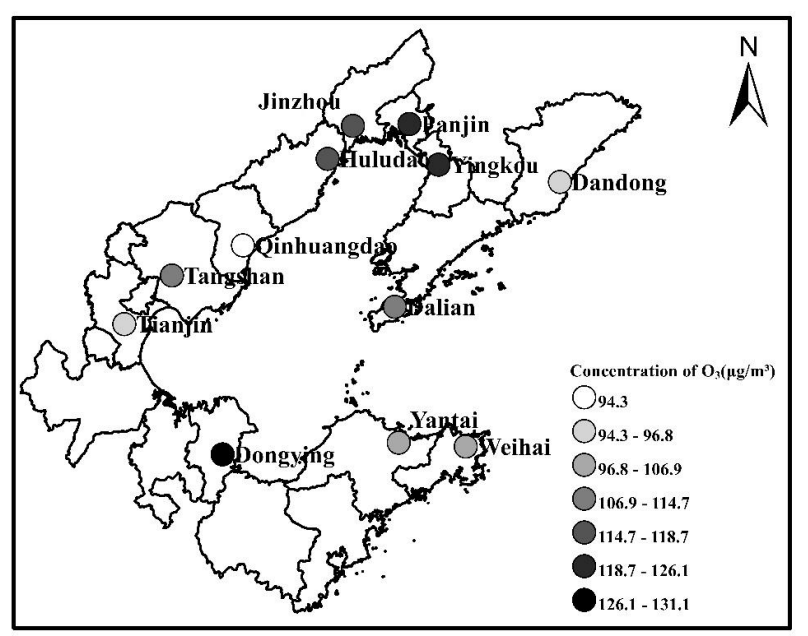

Fig. 3. Spatial distribution of $\mathrm{O}_{3}$ concentrations in the Bohai Bay area. emissions from airborne pollutants [19]. They all have similar sources of pollution in the Bohai Bay area, thus the concentration of $\mathrm{O}_{3}$ in coastal and non-coastal cities did not show any significant difference.

According to the correlation analysis between the distance from the sea and the $\mathrm{PM}_{2.5}$ pollution factors such as $\mathrm{PM}_{2.5}$, we found that there are significant correlations between $\mathrm{PM}_{2,5}, \mathrm{PM}_{10}$ and $\mathrm{NO}_{2}$, and the correlation coefficients are $0.786^{* *}, 0.635^{*}$ and $0.584^{*}$, respectively. The main reason is that the coastal cities were influenced by clean air from the Bohai Bay area, which can help dilute the local pollutants [20]. However, non-coastal cities including Tangshan, Tianjin and other heavy industrial cities, were due to not only their own serious pollution problems [21-22]. At the same time, compared with coastal cities, the diffusion of pollutants is also slow. Under the combined influence, the difference of $\mathrm{PM}_{2.5}$ concentration between the coastal cities and non-coastal cities is significant.

\section{Monthly Change Characteristics of $\mathrm{PM}_{2.5}$}

As shown in Fig. 4, the concentration of $\mathrm{PM}_{2.5}$ in coastal cities is lower than that in non-coastal cities, and the trend is consistent. In the period of January, March, November and December, during these four months, $\mathrm{PM}_{2.5}$ pollution was the most serious, whereas in July, August and September, the pollution was relatively light. The lowest concentration shown by season was in the summer, followed by autumn, while winter and spring showed the highest concentration. There is more rainfall in summer and it is calculated that there is a significant negative correlation between rainfall and $\mathrm{PM}_{2.5}$, and the correlation is up to $-0.692 *$. At the same time, there is a strong wind in the rain, and it has a good settlement and dilution to the air pollutants. In addition, the solar radiation in summer and autumn is strong, and the convective conditions are better than other seasons, which can help accelerate the spread of air pollutants [23-24]. However, there is little precipitation in the winter and spring, and the atmosphere is stable, and

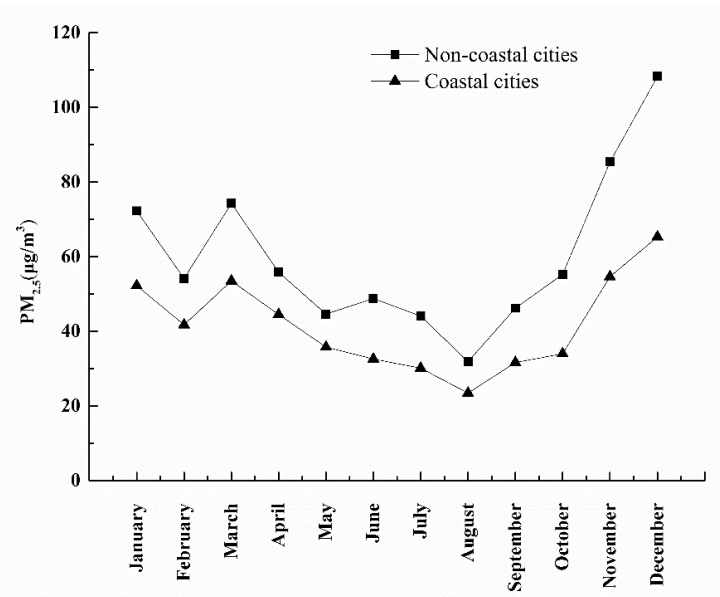

Fig. 4. Coastal and non-coastal city $\mathrm{PM}_{2.5}$ monthly changes. 


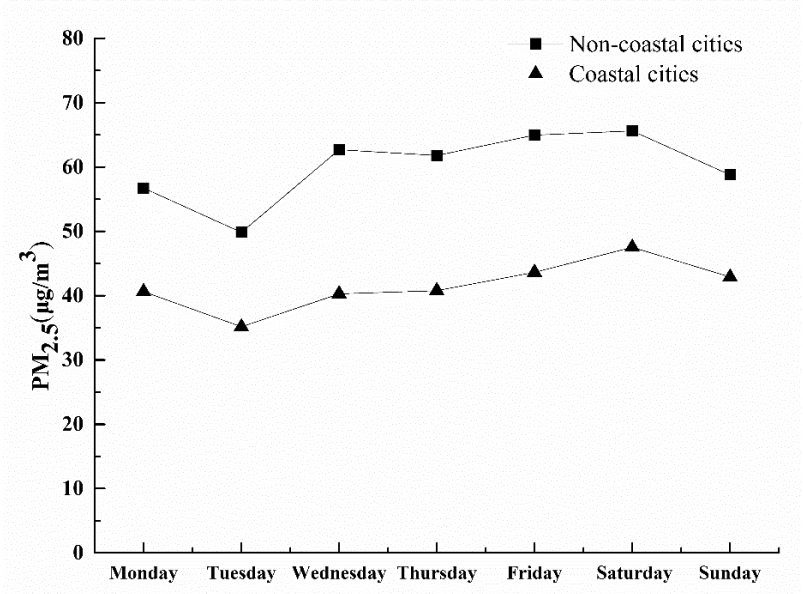

Fig. 5. $\mathrm{PM}_{2.5}$ weekly changes in coastal and non-coastal cities.

reverse temperature is prone to occur in the morning and at night, causing the accumulation of contaminants in the near strata. Moreover, in winter and spring the pollutants may be transported from the inland to the coastal cities, and this also may result in a higher concentration of pollutants in winter and spring [25-26].

\section{$\mathrm{PM}_{2.5}$ Week Change}

It is generally acknowledged that industrial enterprises stopped production and the number of people going out was reduced on weekends. The $\mathrm{PM}_{25}$ concentration showed the phenomenon that the weekend was lower than the working day, which was the "weekend effect" [27]. Our study found that the $\mathrm{PM}_{2.5}$ changes on the working days and weekends in coastal cities and non-coastal cities were relatively stable, and did not show a significant "weekend effect" (Fig. 5). This may be because the economically

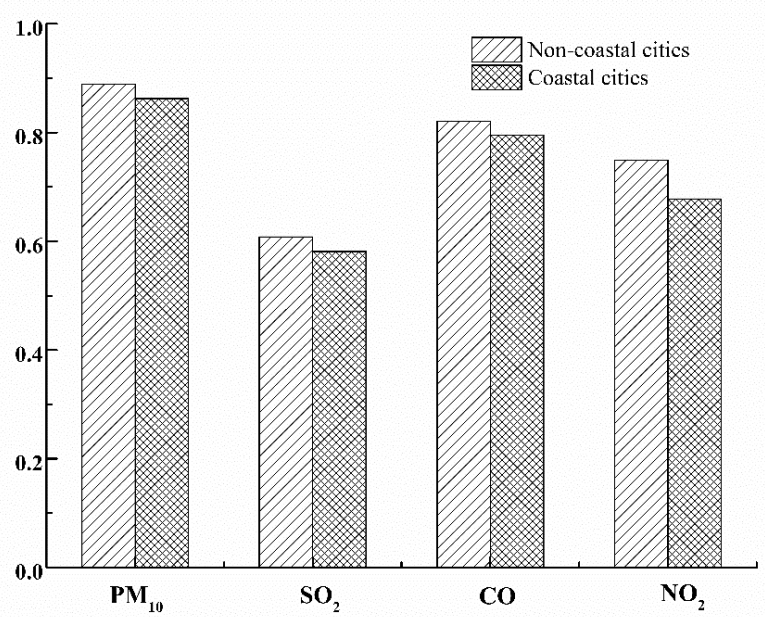

Fig. 6. Correlation between $\mathrm{PM}_{10}, \mathrm{SO}_{2}, \mathrm{CO}, \mathrm{NO}_{2}$ and $\mathrm{PM}_{2.5}$ in coastal and non-coastal cities. developed population in the bay area frequented on weekends and working days and the use of motor vehicles is large.

\section{Correlation Analysis}

Fig. 6 shows that the correlation coefficients of $\mathrm{PM}_{10}$, $\mathrm{SO}_{2}, \mathrm{CO}, \mathrm{NO}_{2}$ and $\mathrm{PM}_{25}$ in coastal cities are lower than those in non-coastal cities, but they show strong positive correlation. These correlation coefficients are $0.889,0.862,0.608,0.581,0.821,0.795,0.749$, and 0.678 respectively, which indicates that the pollutants in the bay area are still mainly from anthropogenic sources [28].

As can be seen from Table 3, the correlation between $\mathrm{O}_{3}$ and $\mathrm{PM}_{2.5}$ is weak, mostly showing the negative correlation. When the amount of pollutant emissions is relatively large, and in addition of the adverse weather conditions, $\mathrm{PM}_{2.5}$ easily becomes the main pollutant. However, $\mathrm{O}_{3}$ is easily formed in high temperature and high light conditions, and it is partially lost by catalytic reaction with $\mathrm{NOx}, \mathrm{HOx}$, and $\mathrm{ClOx}$ [26]. The formation conditions between these two are contradictive to a certain extent, which leads to its negative correlation [29].

Our study has shown that the population, car ownership, gross regional product and energy consumption are significantly related to $\mathrm{PM}_{2.5}$ [30-31], but it is very interesting that no similar results were found in this study. We think that this may be caused by two reasons. The first is that the city is close to the sea, the non-coastal cities, which is the farthest distance from the sea, is only $50 \mathrm{~km}$ from the sea. Therefore, it is still under the clean effect of the ocean air mass, which leads to deviation from previous research. Second, this study only selected 1 year and 12 cities, and the data were relatively small and need to be studied further.

Table 3. Correlation between $\mathrm{O}_{3}$ and $\mathrm{PM}_{2.5}$ in each city.

\begin{tabular}{|c|c|c|}
\hline \multirow{4}{*}{ Coastal Cities } & City & Correlation Coefficient \\
\cline { 2 - 3 } & Dalian & -0.066 \\
\cline { 2 - 3 } & Dandong & -0.007 \\
\cline { 2 - 3 } & Waihai & $0.148^{* *}$ \\
\cline { 2 - 3 } & Yantai & -0.032 \\
\cline { 2 - 3 } & Yingkou & $-0.221 * *$ \\
\cline { 2 - 3 } & Qinhuangdao & -0.045 \\
\cline { 2 - 3 } Cities & Huludao & $-0.150^{* *}$ \\
\cline { 2 - 3 } & Dongying & $-0.120^{*}$ \\
\cline { 2 - 3 } & Jinzhou & $-0.199^{* *}$ \\
\cline { 2 - 3 } & Panjin & -0.078 \\
\cline { 2 - 3 } & Tangshan & $-0.205^{* *}$ \\
\cline { 2 - 3 } & Tianjin & $-0.235^{* *}$ \\
\hline
\end{tabular}




\section{Conclusions}

Based on the analysis of the long-term monitoring data, its spatiotemporal distribution characteristics of pollution factors of the urban agglomeration in the Bohai Bay area of China in 2016 have been investigated in detail.

(1) The concentrations of $\mathrm{PM}_{2.5}, \mathrm{PM}_{10}$, and $\mathrm{O}_{3}$ in the Bohai Bay area and the noncompliance rates are all higher in non-coastal cities than in coastal cities.

(2) Based the analysis of the spatial distribution of $\mathrm{PM}_{2.5}$ and $\mathrm{O}_{3}$ in 2016 and the identification of independent samples, the $\mathrm{PM}_{2.5}$ concentration in coastal cities and non coastal cities was significantly different, but there was no significant difference in $\mathrm{O}_{3}$.

(3) From the monthly concentration change of $\mathrm{PM}_{2.5}$ in coastal and non-coastal cities, in January, March, November, and December, $\mathrm{PM}_{2.5}$ pollution is the most serious, whereas the period of July, August, and September is the lightest pollution. That is, the concentration value is the lowest in summer, followed by autumn, and the highest concentrations are in winter and spring. No significant "weekend effect" was found in weekly changes.

(4) $\mathrm{PM}_{25}$ is significantly related to $\mathrm{PM}_{10}$ but its correlation is lower than non-coastal cities. The correlation between $\mathrm{O}_{3}$ and various pollution factors is not obvious, and the relationship is more complicated.

In view of the differences in pollution between the coastal cities and non-coastal cities in the Bohai Bay area of China, it is suggested that the bay area formulate pollution control measures according to different regions. This study not only provides a basis for pollution control in the area, but also has important significance for air pollution control in China.

\section{Acknowledgements}

This work was supported by the National Natural Science Fund (41272173), the Foundation of He'nan Educational Committee (16A170001), the Excellent Youth Foundation of Henan Polytechnic University, and the Fundamental Research Funds for the Universities of Henan Province (NSFRF1631).

\section{Conflict of Interest}

The authors declare no conflict of interest.

\section{References}

1. SONG C.B., WU L., XIE Y.C., HE J. J., CHEN X., WANG T., LIN Y.C., JIN T.S.,WANG A.X., LIU Y., DAI Q.L., LIU B.S.,WANG Y.N., MAO H.J. Air pollution in china: status and spatiotemporal variations.Environmental Pollution. 227, 334, 2017.
2. ROOHANI Y.H., ROY A.A., HEO J., ROBIMSON A.L., ADAMS P.J. Impact of natural gas development in the marcellus and utica shales on regional ozone and fine particulate matter levels. Atmospheric Environment. 155, 11, 2017.

3. WU Y.Y., GU B.J., ERISMAN J.W., REIS S., FANG Y.Y., LU X.H., ZHANG X.M. PM ${ }_{25}$ pollution is substantially affected by ammonia emissions in China. Environmental Pollution. 218, 86, 2016.

4. CAO C., JIANG W.J., WANG B.Y., FANG J.H., LANG J.D., TIAN G., JIANG J.K., ZHU T.F. Inhalable microorganisms in Beijing's $\mathrm{PM}_{25}$ and $\mathrm{PM}_{10}$ pollutants during a severe smog event. Environmental Science and Technology. 48 (3), 1499, 2014.

5. XU L.L., DUAN F.K., HE K.B., MA Y.L., ZHU L.D., ZHENG Y.X., HUANG T., KIMOTO T., MA T., LI H., YE S.Q., YANG S., SUN Z.L., XU B.Y. Characteristics of the secondary water-soluble ions in a typical autumn haze in Beijing. Environmental pollution. 227, 296, 2017.

6. WANG Y.Y., ZHANG Y.M., HAN D.H., MENG L., GUO M., DUAN W.B. Analysis on the Pollution Status of the Particulate Matter $\left(\mathrm{PM}_{2.5}\right)$ and the Correlation with Meteorological Factors during Heating Period in Harbin City. Journal of Anhui Agri. 43 (19), 185, 2015.

7. WANG Q., DENG Q.H., TANG M., LIU W.W. Mass concentration and variations of particulate matters $\mathrm{PM}_{10}$ in suburban air of Changsha, China.Journal of Central South University (Science and Technology). 41 (6), 241, 2010.

8. WANG L.L., LIU Z.R., SUN Y., JI D.S., WANG Y.S. Long-range transport and regional sources of $\mathrm{PM}_{25}$, in Beijing based on long-term observations from 2005 to 2010. Atmospheric Research. 157, 37, 2015.

9. HAN L.J., ZHOU W.Q., LI W.F. City as a major source area of fine particulate $\left(\mathrm{PM}_{2.5}\right)$ in China. Environmental Pollution. 206, 183, 2015.

10. SHEN Z.X.,SUN J., CAO J.J., ZHANG L.M., ZHANG Q., LEI Y.L., HUANG R.J., LIU S.X., HUANG Y., ZHU C.S., XU H.M., ZHENG C.L., LIU P.P., XUE Z.G. Chemical profiles of urban fugitive dust $\mathrm{PM}_{2.5}$ samples in northern chinesecities.Science of the Total Environment. s 569-570, 619, 2016.

11. SALAMEH D., DETOURNAY A., PEY J.,PEREZ N., LIGUORI F., SARAGA D., BOVE M.C., BROTTO P., CASSOLA F., MASSABO D., LATELLA A., PILLON S., FORMENTON G., PATTIE S., ARMENGAUDI A., PIGA D., JAFFREZO J.L., BARTZIS J., TOLISE., PRATI P., QUEROL X., WORTHAM H., MARCHAND N. PM 2.5 chemical composition in five European Mediterranean cities: A 1-year study. Atmospheric Research. 155, 102, 2015.

12. HAN L.H., CHENG S.Y., ZHUANG G.S., NING H.B., WANG H.Y., WEI W., ZHAO X.J. The changes and longrange transport of $\mathrm{PM}_{2.5}$ in Beijing in the past decade. Atmospheric Environment. 110, 186, 2015.

13. CHENG Z., LUO L.N., WANG S.X., WANG Y.G., SHARMA S., SHIMADERA H., WANG X.L., BRESSI M., DE MIRANDA R.M., JIANG J.K., ZHOU W., FAJARDO O., YAN N.Q., HAO J.M. Status and characteristics of ambient $\mathrm{PM}_{2.5}$ pollution in global megacities. Environment International. s 89-90, 212, 2016.

14. WANG W., WANG S., QIANG J., ZHOU J.B., LI Y.F., REN Z.K. Pollution episode analysis of typical air pollutants mainly full of $\mathrm{NO}_{2}$ in autumn of shijiazhuang city.Hebei Journal of Industrial Science and Technology. 33 (3), 258, 2016. 
15. ZHAO Z.Z., CAO J.J., LIU S.X. The variations of $\mathrm{CO}_{2}$, $\mathrm{SO}_{2}$ and $\mathrm{O}_{3}$ at an atmospheric background site in Qinghai Lake in summer, northeastern Tibetan Plateau. Journal of Earth Environmental. 3, 201, 2010.

16. CHENG G.,ZHANG C. Desulfurization and Denitrification Technologies of Coal-fired Flue Gas. Polish Journal of Environmental Studies. 2018.

17. ZHOU C.Y., LI Q., HE Y.X., WANG Z.T., CHEN H., ZHANG L.J., MAO H.Q., YU C. Spatial-temporal change of tropospheric $\mathrm{NO}_{2}$ column density and its impact factors over Shandong province during 2005-2014. China Environmental Science. 35 (8), 2281, 2015.

18. WEI J., CHEN X.G., REN Q., ZHANG K.L. Study on the effect of energy structure adjustment on concentration of $\mathrm{SO}_{2}$ in different regions of winter Urumqi. Environmental Pollution and Control. 8, 88, 2013.

19. LI H., LI L., HANG C., AN J.Y., YAN R.S., HUANG H.Y., WANG Y.J., LU Q., WANG Q., LOU S.R., WANG H.L., ZHOU M., TAO S.K., QIAO L.P., CHEN M.H. Ozone Source Apportionment at Urban Area during a Typical Photochemical Pollution Episode in the Summer of 2013 in the Yangtze River Delta. Environmental Science. 36 (1), $1,2015$.

20. SHEN L.J., LI L., LYU S., ZHANG X.H., WU B. Impacts of different air masses on the variations of air pollutants in Jiaxing. Environmental Chemistry. 34 (4), 754, 2015.

21. CHEN Z.Y., CAI J., GAO B.B., XU B., DAI S., HE B., XIE X.M. Detecting the causality influence of individual meteorological factors on local $\mathrm{PM}_{25}$ concentration in the jing-jin-ji region.Scientific Reports. 7, 40735, 2017.

22. PAN B.F., CHENG L.J., WANG J.G., LI W.P., GU P., XU R.J., GONG Z.Y. Characteristics and Source Attribution of Ozone Pollution in Beijing-Tianjin-Hebei Region. Environmental Monitoring in China. 32 (5), 17, 2016.
23. CHEN B.L., WU J.L., LIU Y.F., YAO L.N., KUANG H.Y. Analysis on Characteristics of Air Pollution in Changzhou from 2012 to 2014. Environmental Science and Management. 42 (1), 114, 2017.

24. FONTES T., LI P., BARROS N., ZHAO P.J. Trendsof PM ${ }_{2.5}$ concentrations in China: A long term approach.Journal of Environmental Management. 196, 719, 2017.

25. XU B.H., DU Y., HU J.C., SUN W.W., FENG J.L. Characteristics of water-soluble organic nitrogen in $\mathrm{PM}_{2.5}$ in Shanghai.Geochimica. 45 (2), 190, 2016.

26. CHAKRABARTY D.K., PESHIN S.K. Latest seasonal trend of aerosol, particulate matter and ozone in Delhi. MAUSAM. 67 (3), 619, 2016.

27. LEI Y., ZHANG X.L.,TANG Y.X., FANG G.Z., ZHOU D.W. Holiday effects on $\mathrm{PM}_{25}$ and other major pollutants in Beijing. Acta Scientiae Circumstantiae. 35 (5), 1520, 2015.

28. MIAO Y.C., WANG J., MA Y.H., YANG W., GU C. Correlation analysis based on PLS1 between $\mathrm{PM}_{25}$ and air pollutants in Tianjin City. Journal of Environmental Engineering Technology. 7 (1), 39, 2017.

29. LUO Y.P., LIU M.J., GAN J., ZHOU X.T., JIANG M., YANG R.B. Correlation study on $\mathrm{PM}_{2.5}$ and $\mathrm{O}_{3}$ mass concentrations in ambient air by taking urban cluster of Changsha, Zhuzhou and Xiangtanas an example. Journal of Safety and Environment. 15 (04), 313, 2015.

30. WANG X.Y., LIU M.X., ZHANG Y.L., WANG L.L., ZHANG H.L. Study of the Relationship between Urbanization Process and Air Pollution in Wuhan City. Environmental Protection Science. 42 (01), 77, 2016.

31. ZHANG Q., HUANG C.Q., GONG Z.Y., JIA.G.S. Analysis of Correlation Relationship of Population,Economy,Energy Consumption and Atmospheric Environmental Pollution in Beijing-Tianjin-Hebei Region.Guangzhou Chemical Industry. 45 (08), 138, 2017. 